\title{
Buchbesprechungen 1919-1945
}

The Great War and Veterans' Internationalism. Ed. by Julia Eichenberg and John Paul Newman, New York: Palgrave Macmillan 2013, 248 S., \$ 95.00 [ISBN 978-1-137-28161-6]

Besprochen von Heather Jones: London, E-Mail: H.S.Jones@lse.ac.uk

DOI 10.1515/mgzs-2016-0116

It could have all been so different: the interwar period that emerges from this fine study of First World War veterans' movements is one where champions of peace and reconciliation abound. Drawing on Wolfgang Schivelbusch's work, this volume is structured around the idea that the end of the war created cultures of victory and defeat and argues that veterans' internationalism - their involvement with their peers from other countries to campaign for international stability, peace and veterans' welfare rights - helped dismantle these cultural divisions. Central to this was the work of FIDAC (Fédération Interalliee des Anciens Combattants), the international umbrella association of veterans' movements from the former Allied countries, with a membership of some 8 million by 1933, and CIAMAC (Conférence Internationale des Associations de Mutilés et Anciens Combattants), the international association of disabled ex-servicemen, membership approximately 4 million (p. 199). CIAMAC included members from both former Entente and Central Power states, while FIDAC invited ex-enemy veterans to some of its events. Both organisations were stalwart supporters of the League of Nations - and of interwar disarmament as Thomas Richard Davies's chapter shows. FIDAC and CIAMAC jointly demonstrated in Geneva in support of the World Disarmament Conference in 1933 (p. 195).

Veterans' movements were, as this volume argues, a transnational phenomenon; although most chapters focus on one country's veterans, they also explore their transnational interactions in-depth. A key strength is the book's integration of Eastern and Western European case studies. Here the stereotype that interwar Eastern Europe was somehow »other «, is debunked in strong chapters on Poland, Yugoslavia and Czechoslovakia by Julia Eichenberg, John Paul Newman and Natali Stegmann. There were close links between veterans' associations in Eastern Europe and their western counterparts, in particular through FIDAC and CIAMAC, and grassroots mobilisation of veterans into ex-servicemen's organisations in the east followed similar models to the west, even if ethnic fractures caused problems - in the case of Czechoslovakia, Stegmann highlights how Germanspeaking ex-servicemen had their own association and felt discriminated against 
in the 1920s. Former legionnaires were also privileged over other groups who had fought in the Austro-Hungarian army. United States veterans were also internationally active as Stephen Ortiz's chapter shows - within a year of its 1919 foundation 843013 veterans joined the American Legion known for its antiBolshevism and support for military preparedness as a way of maintaining international peace, yet nevertheless also significantly involved in FIDAC.

By 1935, the international situation deteriorating, disillusionment had set in: the president of the French veterans' movement, the Union Fédérale, Henri Pichot, in 1935 somewhat acerbically, described FIDAC as little more than a "generous travel agency« (p. 171). Yet such negativity belied the real successes of veterans' movements both internationally and nationally. As the editors argue, what emerges from this history is a challenge to the "brutalization« thesis of George Mosse and others, regarding how the First World War impacted upon European politics and societies by promoting violence. Although in the majority more »antiwar « than absolutely pacifist, veterans' organisations' international activism, and, in particular, their bringing together former enemies, genuinely contributed to demobilising war mentalities and lobbying for veterans' rights. Ex-servicemen's organisations constituted four-fifths of the membership of the League of Nations movement in France (p. 199). In July 1936 thousands of veterans from 18 countries, including Italy and Germany, met on the Verdun battlefield and swore an oath to uphold peace (p. 207). There were also longer-lasting achievements. As Antoine Prost points out, French veterans lobbied for recompense from the state for their war damages not on the grounds of charity but in terms of what they saw as their civic right to reparation, a first step in the battle »to make states recognize the rights of their citizens« (p. 30). This work, led by figures such as René Cassin, would become the "project of a whole generation which traversed the two world wars « (p. 31), as epitomized by Cassin's later role in bringing about the Universal Declaration of Human Rights in 1948.

Ultimately, this book suggests the rise of an expansionist, aggressive Nazi Germany caused interwar veterans' internationalism to fail. Niall Barr explores the way in which British veterans' (and indeed many German veterans') aspirations to preserve peace were manipulated and exploited by Hitler and his new regime: the British Legion became so focused upon the preservation of peace that they offered to provide veterans to police the secessation of part of Czechoslovakia to Germany - over 17000 members volunteered (p. 46). William Mulligan argues that the failure of the Reichsbanner Schwarz-Rot-Gold, the main German association involved in veterans' internationalism, to provide for German veterans' material needs in the interwar period badly undermined it at home. Martina Salvante shows how disabled veterans in the Associazione Nazionale Mutilati $e$ Invalidi di Guerra (ANMIG) in Italy, were successfully co-opted into the fascist 
state - including supporting its 1935 invasion of Ethiopia - while remaining within FIDAC, nominally at least committed to the organisation's pursuit of international peace, a difficult contradictory position (p. 174). This was symptomatic of the broader problem facing veterans' internationalism as John Horne points out in an excellent chapter on the powerful cultural status of the veteran in the interwar period. In order to remain unified, veterans' movements from different countries had to steer clear of ideological politics - and the Treaty of Versailles - subjects which might divide them: »to engage in ordinary politics was to threaten the solidarity on which the cause was premised « (p. 212). Their ability to really address international divisions was thus limited.

This volume is not without weaknesses: some of the translations are in places clunky. Not all chapters engage fully with the thematic idea of cultures of victory and of defeat. There could also be more on the darker side of veterans' movements: their often complex, militant nationalist attitudes. Proto-fascistic organisations such as the Stahlhelm are also only briefly covered. Yet, this is a strong book, exploring uncharted historiographical territory, with original contributions and a sophisticated, thought-provoking introduction. By revealing the extent of the role played by Great War veterans in working for a peaceful international future Eichenberg and Newman's volume is of immense value - in particular, as they argue, by shaking up the traditional view of interwar chronology which focuses on diplomatic failures and rising tensions rather than disarmament and reconciliation. The lights may have failed but this book reveals they burned very brightly for longer and in far more places than previously acknowledged. 